1984 American Olympic team about $11 \%$ of athletes had asthma or exercise induced bronchoconstriction.' The figures agreed with those of Weiler et al, who found self reported asthma in $12 \%$ of football players; basketball players had a low asthma prevalence. ${ }^{29}$ In a study from Portugal Gomes et al found normal bronchial responsiveness in élite runners. ${ }^{30}$ In another study swimmers had a higher prevalence of asthma and bronchial hyperresponsiveness than other athletes and the authors postulated a relation with ambient swimming pool conditions. ${ }^{31}$

To our knowledge there are no other studies of skiers or other athletes performing exercise at low temperatures. From the few reports available there is no evidence that strenuous training by itself increases the risk of asthma. Strenuous training at low temperatures, however, seems to be pathogenetic for asthma, possibly due to the repeated breathing of large amounts of cold air.

The expert technical help of Britt-Marie Sundblad and Wang Zhi-Ping is acknowledged. We thank the department of clinical physiology, Hospital of Östersund, for spirometry. The study was partly financed by grants from the Swedish National Centre for Research in Sports.

1 Voy RO. The US Olympic committee experience with exercise-induced bronchospasm. Med Sci Sports Exerc 1984;18:328-30.

2 Larsson L, Hemmingsson P, Boethius G. Self-reported obstructive airwa symptoms are common in young cross-country skiers. Scandinavian fournal of Medicine and Science in Sports (in press).

3 Strauss RH, McFaddan ER, Ingram RH, Jaeger J. Enhancement of exerciseinduced asthma by cold air. N Engl f Med 1977;297:743-7.

4 Strauss RH, McFadden ER, Ingram RH, Deal EC, Jaeger J. Influence of heat and humidity on the airway obstruction induced by exercise in asthma. IClin Invest 1978;61:433-40.

5 Larsson K, Hendenström H, Malmberg P. Learning effect, variation during office hours and reproducibility of static and dynamic spirometry. office hours and reproduci
Respiration 1987;51: 214-22.

6 Hendenström H, Malmberg P, Fridriksson HV. Reference values for lung function tests in men: regression equations with smoking variables. Ups $\mathcal{F}$ Med Sci 1986;91:299-310.

7 Hedenström H, Malmberg P, Agarwal K. Reference values for lung function tests in females. Regression equations with smoking variables. Clinica Respiratory Physiology 1985;21:551-8.

8 Malmberg $\mathrm{P}$, Larsson $\mathrm{K}$, Thunberg $\mathrm{S}$. Increased lung deposition and biological effect of methacholine by use of a drying device for bronchial provocation tests. Eur Respir F 1991;4:890-8.

9 Amariv I, Plit M. Temperature and relative humidity response to inhaled histamine in normal subjects. Am Rev Respir Dis 1989;140:1416-20.

10 Dosman JA, Hodgson WC, Cockcroft DW. Effect of cold air on bronchial response to inhaled histamine in patients with asthma. Am Rev Respir Dis response to inhaled 1 144:45-50.

11 Litmanen H, Pekkarinen H, Randell J, Kononoff A, Tukiainen H. Airway response to inhaled histamine after exercising in the cold in healthy subjects. Eur Respir f 1992;5(suppl 15):445s.
12 Larsson L, Boethius G, Uddenfeldt M. Differences in utilization of asthma drugs between two neighbouring Swedish provinces: relation to symptom reporting. Eur Respir f 1993;6:198-203.

13 Lundbäck B, Nyström L, Rosenhall L, Stjernberg N. Obstructive lung disease in northern Sweden: respiratory symptoms assessed in a postal survey. Eur Respir f 1991;4:257-66.

14 Larsson L, Boethius G, Uddenfeldt $M$. Differences in utilization of asthma drugs between two neighbouring Swedish provinces-relation to prevalence of obstructive airway disease. Thorax (in press).

15 Morton AR, Papilia SM, Fitch KD. Is salbutamol ergogenic? the effects of salbutamol on physical performance in high-performance nonasthmatic athletes. Clinical foumal of Sport Medicine 1992;2:93-7.

16 McKenzie DC, Rhodes EC, Stirling DR, Wiley JP, Dunwoody DW, Filsinger IB, et al. Salbutamol and treadmill performance in non-atopic athletes. Med Sci Sports Exerc 1993;15:520-2.

17 Freeman W, Packe GE, Cayton RM. Effect of nebulised salbutamol on maximal exercise performance in men with mild asthma. Thorax 1989;44: 942-7.

18 Choo J, Horan MA, Little RA, Rothwell NJ. Anabolic effects of clenbuterol on skeletal muscle are mediated by $\beta 2$-adrenoceptor activation. Am $\mathcal{J}$ Physiol 1992;263:E50-6.

19 Beerman DH, Butler WR, Hogue DE, Fishell VK, Dalrymple RH, Ricks CA et al. Cimaterol-induced muscle hypertrophy and altered endocrine status in lambs. F Anim Sci 1987;65:1514-24.

20 Martinez JA, Portillo MP, Larralde J. Anabolic actions of a mixed $\beta$ adrenergic agonist on nitrogen retention and protein turnover. Horm Metab Res 1991;23:590-3.

21 Signorile JF, Kaplan TA, Applegate B, Perry AC. Effects of acute inhalation of the bronchodilator, albuterol, on power output. Med Sci Sports Exerc 1992;24:638-42.

22 Martineau L, Horan MA, Rothwell NJ, Little RA. Salbutamol, a $\beta 2$ adrenoceptor agonist, increases skeletal muscle strength in young men. Clin Sci 1992;83:615-21.

23 Kerrebijn KF, Essen-Zandvliet EEM van, Neijens HJ. Effect of long-term treatment with inhaled corticosteroids and beta-agonists on the bronchial responsiveness on children with asthma. I Allergy Clin Immunol 1987;79: respons.

24 Kraan J, Koeter GH, Mark WVD, Sluiter HJ, Vries KD. Changes in bronchial hyperreactivity induced by 4 weeks of treatment with antiasthmatic drugs in patients with allergic asthma: a comparison between budesonide and terbutaline. $\mathcal{f}$ Allergy Clin Immunol 1985;76:628-36.

25 Torén $\mathrm{K}$, Brisman J, Järvholm B. The assessment of asthma and asthma-like symptoms in adults using questionnaires-a literature review. Chest (in press).

26 Larsson K, Martinsson A, Hiemdahl P. Influence of $\beta$-adrenoceptor function during terbutaline treatment on allergen sensitivity and bronchodilato response to terbutaline in asthmatic subjects. Chest 1992;101:953-60.

27 van Schayck CP, Graafsma SJ, Visch MB, Dompeling E, van Weel C, van Herwarden LA. Increased bronchial hyperresponsiveness after inhaling Herwaarden $L A$. salbutamol during 1 year is not caused

28 Vathenen AS, Knox AJ, Higgins BG, Britton IR, Tattersfield AE. Rebound increase in bronchial responsiveness after treatment with inhaled Rebound increase in bronchial resp
terbutaline. Lancet 1988;i:554-8.

29 Weiler JM, Metzger WJ, Donnelly AL, Crowley ET, Sharath MD. Prevalence of bronchial hyperresponsiveness in highly trained athletes. Chest 1986;90 23-8.

30 Gomes I, Figueiredo MM, Oliveira J, Almeida J, Coelho M, Marques A Bronchial responsiveness to inhaled methacholine in well trained runners. Eur Respir f 1992;5(suppl 15):455s.

31 Drobnic F, Banquells M, Casan P, Miralda R, Sanchi J, Freixa A, et al. Bronchial hyperresponsiveness in elite sportsmen. Eur Respir f 1992, 5(suppl 15):456s.

(Accepted 10 September 1993)

\section{Importance of placement of intra-articular steroid injections}

\section{A Jones, M Regan, J Ledingham, M Pattrick, A Manhire, M Doherty}

Rheumatology Unit, City Hospital, Nottingham NG5 1PB

A Jones, research fellow M Regan, senior registrar $\mathrm{J}$ Ledingham, research fellow A Manhire, consultant radiologist

M Doherty, senior lecturer

Manchester General Hospital, Manchester M8 7PJ

M Pattrick, consultant physician

Correspondence to: Dr Jones.

$B M \mp 1993 ; 307: 1329-30$
Intra-articular corticosteroid injections are widely used in clinical practice, but their effect is variable and their value remains doubtful. ${ }^{1}$ One possible explanation for this variability might be inaccurate injection. We conducted this study to determine the accuracy of joint injections, factors associated with inaccuracy, and the effect of placement on clinical response.

\section{Patients, methods, and results}

The study was approved by the local hospital ethics committee. Patients in whom intra-articular steroid injections were indicated were asked if they wished to participate. After patients had given informed consent, synovitis in the index joint ${ }^{23}$ and at other sites was assessed. ${ }^{4}$ Local synovitis was graded according to an articular index developed for use at the knee. An "active," inflamed knee is defined by the presence of three or more of the following: stiffness lasting for more than 30 minutes in the early morning or after inactivity, synovial thickening, local warmth, tenderness, and moderate synovial effusion. ${ }^{23}$ Depot methylprednisolone was used for all injections and was mixed with a radiographic contrast medium, iopamidol. The index joint was aspirated and injected, and the patient had a single plain radiograph of this joint. Patients were reviewed at six weeks by the same assessor; the Ritchie index and the assessment of synovitis were repeated blind to the results of the previous radiological clinical findings. ${ }^{2-4}$ Radiographs were read blind by one consultant radiologist (AM). Results were analysed by a $\chi^{2}$ test.

Overall, 109 patients were studied; their median age was 68 (range 23-89). Forty four patients had rheumatoid arthritis, 52 osteoarthritis, and 13 other disease. The joints injected and the accuracy of placement at each joint site are shown in the table. One patient failed to attend for radiography and thus 108 radiographs were evaluable. Fifty six injections were intra-articular and 31 extra-articular; in 21 the location was uncertain because of a lack of contrast in the radiograph. 
Accurate injection was associated with successful aspiration of synovial fluid (38/56 intra-articular injections had had successful aspiration compared with $4 / 21$ uncertain injections and 14/31 extra-articular injections; $x^{2}=15 \cdot 4, \mathrm{df}=2, \mathrm{p}<0 \cdot 0005$ ).

Six patients did not attend at six weeks, leaving 102 patients in whom clinical response could be studied. A reduction in joint inflammation (active becoming inactive) was associated with accuracy of injection-28 out of 54 intra-articular injections, seven out of 30 extra-articular injections, and 10 out of 18 uncertain injections were associated with improvement $\left(\chi^{2}=7 \cdot 52\right.$, $\mathrm{df}=2, \mathrm{p}<0.05$ ). Only patients in whom a joint was initially classified as active would be able to show reduction in inflammation, so data on this group were analysed separately. Results were similar (28/47 intraarticular injections, 7/19 extra-articular injections, and $10 / 17$ uncertain injections were associated with improvement, $\chi^{2}=3 \cdot 0, \mathrm{df}=2, \mathrm{p}=0 \cdot 22$ ); none of the patients with initially inactive inflammation developed active inflammation. When local effects on the joint were taken into account-that is, the index joint was removed from the Ritchie index-accuracy of injection had no significant effect on the Ritchie index.

The doctors who gave the injections were a consultant, two senior registrars, and two research registrars in rheumatology; the accuracy of their injections was one out of two, four out of 11,16 out of 31,33 out of 56 , and 16 out of 31 respectively.

\section{Comment}

This study shows that intra-articular injections are often inaccurate and that this may be clinically important. ${ }^{5}$ Indeed, inaccurate injection might contribute to the incidence of local tissue damage (atrophy of soft tissue and fat). Surprisingly, accuracy at the knee and shoulder - the two most commonly injected joints-was poor. The results obtained in the uncertain
Radiological placement of intra-articular steroid injections in 108 patients

\begin{tabular}{lccc}
\hline Joint & Extra-articular & Uncertain & Intra-articular \\
\hline Knee & 17 & 3 & 39 \\
Shoulder & 6 & 12 & 2 \\
Wrist & 2 & 2 & 4 \\
Thumb carpometacarpal & 1 & 2 & 0 \\
Finger: & & 1 & 0 \\
$\quad$ Metacarpophalangeal & 0 & 1 & 0 \\
$\quad$ Distal interphalangeal & 0 & 0 & 5 \\
Elbow & 1 & 0 & 6 \\
Ankle & 3 & 0 & 0 \\
Acromioclavicular & 1 & 21 & 56 \\
\hline Total & 31 & & \\
\hline
\end{tabular}

group are difficult to interpret and may reflect the different range of joints injected: a high proportion of shoulders and a low proportion of knees. This could certainly explain the lower rate of successful aspiration. Although the doctors who gave the injections had differing rheumatological experience, we were unable to show any effect of seniority. These results may imply, however, that current training in injection techniques needs to be refined.

We thank the Arthritis and Rheumatism Council, United Kingdom, for financial support.

1 McAlindon T, Dieppe P. The medical management of osteoarthritis of the knee: an inflammatory issue? Br $\mathcal{f}$ Rheumatol 1990;29:471-3.

2 Doherty M, Richards N, Hornby J, Powell R. Relationship between synovial fluid $\mathrm{C} 3$ degradation products and local joint inflammation in rheumatoid arthritis, osteoarthritis and crystal associated arthropathy. Ann Rheum Dis 1988;47:190-7.

3 Jones AC, Hopkinson ND, Pattrick M, Berman P, Doherty M. Evaluation of a method of clinical assessment of osteoarthritis of the knee. Ann Rheum Dis method of clinicat

4 Ritchie DM, Boyle JA, McInnes JM, Jasani K, Dalakos G, Grieveson P, et al. Clincal studies with an articular index for the assessment of tenderness in patients with rheumatoid arthritis. Qf Med 1968;37:393-406. 5 Stoker DJ. Intra-articular injections in capsulitis. BMF 1991;303:123.

(Accepted 20 August 1993)

\section{A PATIENT WHO CHANGED MY LIFE}

\section{Acute liver failure and candidate hepatitis $\mathbf{F}$}

He was only 13 years old and I knew him less than one week. Five years later I moved and changed the direction of my career as a consequence of our brief encounter.

He became ill in the summer of 1985 . The flu-like illness progressed relentlessly to acute liver failure. Sporadic non- $A$, non-B hepatitis is the most common, presumed viral, cause of acute liver failure in Britain and the United States. The agents remain unidentified and survival without liver transplantation is below $20 \%$.

We met when he was in grade IV hepatic encephalopathy and awaiting urgent liver transplantation. Two days later he was sitting out of bed and tuned in to a personal radio. One week later the liver failure recurred. The clinical picture resembled a haemorrhagic fever. He bled from multiple sites and died soon after. The graft was swollen and haemorrhagic. There was little evidence of rejection and the surgical anastomoses were faultless.

Electron microscopy showed virus-like particles, resembling arboviruses, in his native liver.' By early 1988 we had collected two further cases. Importantly, abundant particles were found in the haemorrhagic grafts if the liver failure recurred. I believed there was sufficient evidence to implicate a novel agent. We needed a scientist to clone its genome.

The turning point came in October 1988. The designated refrigerator containing the liver bank had thawed mysteriously while I was abroad. Undeterred, I restarted the collection, this time determined to tackle the molecular biology myself. By 1990, five years on, we had a total of nine cases. $^{2}$
In 1991 I moved from south to north London to enter the world of molecular virology. Full time research can be lonely. Fifteen years of clinical practice had made me dependent on the daily rewards of dealing with patients. Science can be exhilarating, especially after a lengthy gestation.

I have tried to justify to other clinicians why I have forsaken temporarily the relative security of clinical medicine in pursuit of science to help solve an uncommon disease. As a clinician I owe a tremendous debt to my scientific colleagues who have found time to teach me and encourage my appreciation of their art. "Nature is nowhere accustomed more openly to display her secret mysteries than in cases where she shows traces of her workings apart from the beaten path; nor is there any better way to advance the proper practice of medicine than to give our minds to the discovery of the usual law of Nature, by careful investigation of cases of rarer forms of disease." 3 -ELIZABETH ANN FAGAN is a Wellcome senior graduate research fellow in London

1 Fagan EA, Ellis DS, Portmann B, Tovey GM, Zuckerman AJ, Williams R. Microbial structures in a patient with sporadic non-A, non-B fulminan hepatitis treated by liver transplantation. $₹$ Med Virol 1987;22:189-98. 2 Fagan EA, Ellis D, Tovey G, Lloyd G, Smith HM, Portmann B, et al. Toga virus-like particles in fulminant sporadic non- $A$, non-B hepatitis and after transplantation. F Med Virol 1992;38:71-7.

3 Garrod A. The debt of science to medicine. BMY 1924;ii:747-52.

We are delighted to receive submissions of up to 600 words on $A$ paper (or patient or book) that changed my practice, $A$ memorable patient, The one message I would like to leave behind, or related topics. 